Jurnal Info Kesehatan

Vol 18, No 2, December 2020, pp. 96-104

P-ISSN 0216-504X, E-ISSN 2620-536X

DOI: 10.31965/infokes.Vol18Iss2.321

Journal homepage: http://jurnal.poltekeskupang.ac.id/index.php/infokes

RES EA R C H

\title{
The Sunrise Model Approach to the Nutritional Status of Toddlers at the Kupang District Primary Health Center
}

\author{
Florentianus Tat ${ }^{1 a^{*}}$, Aben B.Y.H Romana ${ }^{1 b}$, Zainab Binti Mohd Shafie ${ }^{2 c}$ \\ ${ }^{1}$ Department of Nursing, Poltekkes Kemenkes Kupang, Indonesia. \\ ${ }^{2}$ Department of Nursing, Universiti Sultan Zainal Abidin, Malaysia. \\ a Email address: florentianustat@yahoo.co.id

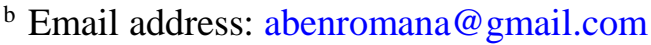 \\ c Email address: zainab69@unisza.edu.my
}

Received: 30 November $2019 \quad$ Revised: 24 August 2020

Accepted: 27 August 2020

\begin{abstract}
Nutritional problems in toddlers are still a major problem in East Nusa Tenggara Province. The results of the 2018 Basic Health Research show the percentage of malnourished babies aged 0-23 months in Indonesia was 3.8\% and malnutrition was $11.4 \%$. East Nusa Tenggara is the province with the highest percentage of malnutrition among children aged 0-23 months in 2018. Nutritional problems have broad dimensions such as socio-economic, cultural, educational, and environmental issues. The research objective is to determine the correlation between the factors in the sunrise model and the nutritional status of the toddler in Kupang district. This study is a quantitative observational study with a cross-sectional design. A convenience sampling was used in this study. The sample consisted of 169 respondents at 26 health centers. The results showed that there was a relationship between the use of health technology with the nutritional status of children under five $(\mathrm{p}=0.023)$, religious beliefs with family philosophy $(\mathrm{p}=0.024)$, family closeness $(\mathrm{p}=0.005)$, cultural and lifestyle factors $(\mathrm{p}=0.007)$, family economy $(\mathrm{p}=0.015)$, parental education $(\mathrm{p}=0.026)$, all variables have a significant relationship with the nutritional status of toddlers $(\mathrm{p}=<0.05)$. It is concluded that there is a significant relationship between the factors in the sunrise model and the nutritional status of children under five in Kupang district. It is suggested that the sunrise model approach can be used to fix nutritional problems in children under five in Kupang Regency.
\end{abstract}

Keywords: Nutritional Status, Sunrise Model

\footnotetext{
*Corresponding Author:

Florentianus Tat

Departmen of Nursing, Poltekkes Kemenkes Kupang

Piet A. Tallo Street, Liliba-Kupang, East Nusa Tenggara, Indonesia

Email: florentianustat@yahoo.co.id

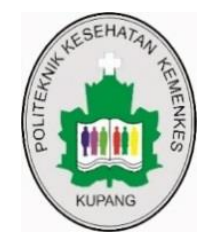

(CThe Author(s) 2020. This article is distributed under the terms of the Creative Commons Attribution 4.0 International License (http://creativecommons.org/licenses/by/4.0/), which permits unrestricted use, distribution, and reproduction in any medium, provided you give appropriate credit to the original author(s) and the source, provide a link to the Creative Commons license, and indicate if changes were made. The Creative Commons Public Domain Dedication waiver (http://creativecommons.org/publicdomain/zero/1.0/) applies to the data made available in this article, unless otherwise stated.
} 
Tat, F., Romana, A.B.Y.H., \& Shafie, Z. B. M. (2020). The Sunrise Model Approach to the Nutritional Status of Toddlers at the Kupang District Primary Health Care. JURNAL INFO KESEHATAN, 18(2),96-104.

\section{INTRODUCTION}

The toddler period is important in the human development process. Growth and development at this age are fast and will never be repeated, therefore, it is often called the golden age. Toddler nutritional status is an important factor that must be considered because the toddler period is a period of development that is vulnerable to nutrition (Fidiantoro \& Setiadi, 2013).

The percentage of toddlers aged 0-59 months according to nutritional status with an index of body weight/age according to the province in 2016 was malnutrition of $6.9 \%$, undernutrition $21.3 \%$, good nutrition $71.3 \%$, over-nutrition $0.5 \%$ (Kemenkes, R.I., 2016). Mapping the nutritional status of toddlers in Indonesia, stated that the lowest nutritional status in Indonesia is East Nusa Tenggara. The coverage of malnourished toddlers who received treatment according to sex, sub-district, and Kupang city health center in 2016 was 278, with the most cases found in Oepoi Primary Health Center with 124 malnourished children under five (Kupang City Health, 2016).

Nutritional problems have a broad dimension, not only related to issues of food, health, and care but also socio-economic, cultural, educational, and environmental issues. One of the factors that influence nutrition problems is culture. The large role of culture will affect individuals and groups concerning the social, economic, political, and cultural aspects of influencing a person in choosing food (type, processing method and consumption method) (Sukardin, 2018). Cultural factors can lead to poverty problems that will have an impact on nutrition problems. Lack of knowledge of mothers about nutrition will result in reduced ability to apply information in daily life (Azrimaidaliza, et al., 2019).

The conceptual model developed by Leininger in explaining nursing care in a cultural context is depicted in the form of a sunrise (Sunrise Model) (Henry, et al., 2010). The assessment was designed based on 7 components in the "Sunrise Model", which are: (1) religious and philosophical factors, (2) social factors and family attachments (kinship and social factors), (3) values culture and lifeways, (4) political and legal factors, (5) economic factors, (6) educational factors, (7) technological factors (Sari \& Prastianty, 2017). Nutrition in children under five is still a major health problem, as evidenced by the high number of malnutrition and malnutrition among children under five. Underweight or malnourished toddlers will experience growth and development problems. which has an impact on the low quality of human life. Various attempts have been made to find the main cause of the problem and even the dominant factors that cause the problem. the cause of nutritional problems in society. This research was conducted to identify the causal factors comprehensively of sunrise model and the nutritional status among toddler factors. Sunrise model is a multi-factor approach to comprehend the causes of problems so that appropriate intervention can be developed. This study examines the multi-factors associated with the occurrence of nutritional problems in children under five in Kupang district and then provides suggestions for joint solutions to all components.

\section{RESEARCH METHOD}

This type of research is a quantitative observational study with a cross-sectional research design. The population in this study were mothers with children under five who visited 26 health centers in Kupang district. The research sample was following the inclusion criteria, namely mothers of children under five who came to visit the health center and were willing to be respondents, as many as 169 mothers of children under five, the sampling technique was using accidental sampling. The research location was 
conducted at 26 health centers in Kupang district. This research was conducted in AugustOctober 2019. This research has received ethical permission from the Ethics Commission for Health Polytechnic, Ministry of Health Kupang with a number: LB. 02.03/1/0007/2019.

\section{RESULTS AND DISCUSSION}

Table 1. Components of the Sunrise Model on the nutritional status of toddlers

\begin{tabular}{|c|c|c|c|c|c|c|}
\hline \multirow{2}{*}{$\begin{array}{l}\text { Sunrise Model } \\
\text { Components }\end{array}$} & & \multicolumn{3}{|c|}{$\begin{array}{l}\text { Nutritional Status of } \\
\text { Babies/Toddlers }\end{array}$} & \multirow[t]{2}{*}{ Total } & \multirow[t]{2}{*}{ p-Value } \\
\hline & & Bad & Less & $\overline{\text { Good }}$ & & \\
\hline \multirow{3}{*}{$\begin{array}{l}\text { Utilization of Health } \\
\text { Technology }\end{array}$} & Low & $8 \%$ & $2 \%$ & $1 \%$ & $11 \%$ & \multirow[t]{3}{*}{0.025} \\
\hline & Medium & $15 \%$ & $18 \%$ & $15 \%$ & $48 \%$ & \\
\hline & High & $13 \%$ & $15 \%$ & $14 \%$ & $41 \%$ & \\
\hline \multirow{3}{*}{$\begin{array}{l}\text { Religion and Philosophy } \\
\text { of Care }\end{array}$} & Low & $4 \%$ & 0 & 0 & $4 \%$ & \multirow[t]{3}{*}{0.050} \\
\hline & Medium & $8 \%$ & $7 \%$ & $7 \%$ & $22 \%$ & \\
\hline & High & $24 \%$ & $27 \%$ & $22 \%$ & $74 \%$ & \\
\hline \multirow[t]{3}{*}{ Family Attachments } & Low & $9 \%$ & $2 \%$ & $2 \%$ & $13 \%$ & \multirow[t]{3}{*}{0.007} \\
\hline & Medium & $21 \%$ & $21 \%$ & $20 \%$ & $62 \%$ & \\
\hline & High & $5 \%$ & $11 \%$ & $8 \%$ & $24 \%$ & \\
\hline \multirow{3}{*}{$\begin{array}{l}\text { Cultural values and } \\
\text { lifestyle }\end{array}$} & Low & $6 \%$ & $1 \%$ & $1 \%$ & $7 \%$ & \multirow[t]{3}{*}{0.006} \\
\hline & Medium & $27 \%$ & $30 \%$ & $24 \%$ & $80 \%$ & \\
\hline & High & $4 \%$ & $4 \%$ & $5 \%$ & $12 \%$ & \\
\hline \multirow[t]{3}{*}{ Economic Status } & Low & $9 \%$ & $4 \%$ & $2 \%$ & $14 \%$ & \multirow[t]{3}{*}{0.017} \\
\hline & Medium & $9 \%$ & $12 \%$ & $7 \%$ & $29 \%$ & \\
\hline & High & $15 \%$ & $17 \%$ & $20 \%$ & $52 \%$ & \\
\hline \multirow[t]{3}{*}{ Parents Education } & Low & $16 \%$ & $11 \%$ & $6 \%$ & $33 \%$ & \multirow[t]{3}{*}{0.001} \\
\hline & Medium & $20 \%$ & $22 \%$ & $20 \%$ & $62 \%$ & \\
\hline & High & $1 \%$ & $2 \%$ & $4 \%$ & $6 \%$ & \\
\hline
\end{tabular}

Table 1 describes the components of health technology utilization shows that most families are in the good category in utilizing health technology, although many still use health technology in the medium category (48\%). Families that do not use health technology have $1 \%$ good nutrition, while families who make good use of health technology, have 14\%, well-nourished children. There are still children under five who are malnourished, even though they have made good use of health technology. There is a significant relationship between the use of health technology and the nutritional status of toddlers as indicated by $\mathrm{p}=0.023$ or $<0.05$.

The Religion and Philosophy of Care component shows that the category of religious and philosophical beliefs in childcare and child feeding is in a good category (74\%). Families that have religious beliefs and philosophies in childcare in the good category have good children's nutritional status. There is a significant relationship between religious beliefs and family philosophy with the nutritional status of toddlers as indicated by $\mathrm{p}=0.024(\mathrm{p}<0.05)$. 
Tat, F., Romana, A.B.Y.H., \& Shafie, Z. B. M. (2020). The Sunrise Model Approach to the Nutritional Status of Toddlers at the Kupang District Primary Health Care. JURNAL INFO KESEHATAN, 18(2),96-104.

The results of the study related to family attachments showed that most of the categories of family attachments were in the moderate category, which was $62 \%$, only $24 \%$ of families were in a good category. The most malnutrition status occurs in families with a moderate attachment category. The dependency category of a moderate family or a family that is not fully tied to other families and shows that the family is more independent. There was a significant relationship between family ties and the nutritional status of toddlers, namely $\mathrm{p}=0.005(<0.05)$.

The results of research on cultural values and lifestyle showed that the category of cultural values in caring for children was mostly in the medium category (80\%), while the good category was $12 \%$. Cultural values and lifestyle still dominate in childcare. The family still refers to cultural values in providing care to children. There is a significant relationship between cultural and lifestyle factors with the nutritional status of toddlers $\mathrm{p}=0.007$.

The results of the study on the economic status of the family showed that most families received good economic support (52\%) in providing care for children. However, there are still $29 \%$ of families who have support in the medium category. Families with good economic status tend to have children with good nutritional status (20\%). There is a significant relationship between the economic status of the family and the nutritional status of toddlers $\mathrm{p}=0.015(\mathrm{p}<0.05)$.

The results of the study related to parental education show that the education category which includes the level of education, the ability to receive health education and the ability to study independently in the toddlers families in Kupang Regency is mostly in the medium category (62\%), and 33\% in the low education category. Although families have higher formal education, there are still some who do not understand good health or nutrition education for children. There is a significant relationship between the educational variables of parents and the nutritional status of toddlers $\mathrm{p}=0.026(<0.05)$.

\section{a. Utilization of Health Technology}

The use of health technology by families includes ownership of health card or Kartu Menuju Sehat (KMS), utilizing supplementary feeding and providing exclusive breastfeeding. The results showed that most families in the good category use health technology, although there are still many who use health technology in the medium category $(48 \%) .1 \%$ of children who do not use health technology have good nutrition, while families who use health technology properly, have children who are well-nourished $14 \%$. Still, children with poor nutrition, even though they have made good use of health technology. There is a significant relationship between the use of health technology and the nutritional status of toddlers as indicated by $\mathrm{p}=0.023$ or $<0.05$.

The KMS is a monitoring tool for mothers to see the development of their babies every month. KMS will be filled properly if the mother brings the children to maternal health care every month. The use of the KMS-health card is to monitor the growth of children under five is very effective and useful for detecting growth disorders such as malnutrition or malnutrition (Tristanti \& Risnawati, 2017). The card towards health is a mandatory guide for all mothers toddlers, to know the development of toddlers' health. The health card also contains all information related to children's health, especially the growth and development of children, in addition to stimulation of growth at every developmental period. Mothers who use KMS properly can follow the growth and development of toddlers. Fitriyanti \& Mulyati's study, (2012) shows that there is a 
statistically significant relationship between the pattern of breastfeeding $(p=0.000)$ and complementary feeding $(\mathrm{p}=0.000)$ with the growth chart of babies on KMS. It means that mothers who give breast milk well can follow the growth and development of toddlers under KMS.

According to the results above, there are still many families who do not make good use of KMS. Meiranny (2018) supported that there are still many mothers under five who do not know about KMS (63.8\%). Lack of knowledge resulted in many toddlers who did not gain weight $(80.9 \%)$. There is a relationship between the mother's level of knowledge about KMS and the growth of children under five $(\mathrm{p}=0.007)$. The low knowledge of mothers under five causes a lack of use of KMS by mothers under five. Tulu, (2018) stated that the knowledge of mothers under five about KMS is still lacking, so it is necessary to increase the socialization of cadres to mothers of toddlers at maternal health center so that they can understand and understand KMS better. By using KMS, growth disorders or the risk of excess nutrition can be detected earlier so that preventive action can be taken more quickly and precisely before the problem is more severe (Sudirman, \& Moonti, 2019).

There are still many families who have not taken advantage of the supplementary feeding program (PMT). One of the efforts to overcome malnutrition is by providing additional recovery food (PMT-P) in which nutritional value has been measured so that nutritional needs can be met. The growth of children under the red line affects the supplementary feeding intervention, meaning that there is an effect of supplementary feeding on the growth of children under the red line (Poernomo \& Anggraeni, 2011). It shows that supplemental feeding has an impact on changes in nutrition in children under five experiencing nutritional problems It is in line with research that there is a difference in weight before and after giving PMT-P $(\mathrm{p}=0.001)$, there is a correlation between energy intake and changes in body weight $(\mathrm{p}=0.001)$, and there is a relationship between protein intake and body weight changes $(\mathrm{p}=0.001)$ (Retnowati, et al., 2015). The provision of additional food in the form of modification is significant for improving the nutritional status of children under five is better (Iskandar, 2017).

Exclusive breastfeeding is the behavior of giving breast milk only to babies until the age of six months without other food and/or drinks. Breast milk in sufficient quantities is the best food for babies and can meet the nutritional needs of the baby for the first 6 months. Exclusive breastfeeding is important, long-lasting, and cost-effective intervention to help reduce toddlers morbidity and mortality. However, most babies are not exclusively breastfed as recommended by the World Health Organization (Asemahagn, 2016).

\section{b. Religion and Philosophy}

Religiosity and philosophy include the existence of religion, perspective on disease and treatment/religious habits that have a positive effect on health. The factors of religiosity and philosophy that can be studied include religious practices, consultation with traditional healers, the meaning of life, individual strength, beliefs, spirituality and health, personal values, religious norms, and beliefs. The results showed that the category of religious and philosophical beliefs in childcare and feeding for children was in a good category and there was a significant relationship between religious beliefs and family philosophy with the nutritional status of toddlers. Rohmatun \& Dewi, (2017) stated that knowledge and religious norms have a positive and significant effect on consumer attitudes towards the intention to consume halal food and beverage products. There are 
Tat, F., Romana, A.B.Y.H., \& Shafie, Z. B. M. (2020). The Sunrise Model Approach to the Nutritional Status of Toddlers at the Kupang District Primary Health Care. JURNAL INFO KESEHATAN, 18(2),96-104.

still many families that apply religious practices in the care of children, including the pattern of feeding. Certain types of food can be given to children according to religious beliefs and family philosophy.

\section{c. Family Attachments}

The main function of the family is to adapt so that children consume foods that contain various kinds of nutritional needs needed by children. Children who experience problems or problems in consuming food, parents help children in dealing with dietary problems, for instance, such as by replacing foods that the child prefers, but the food still has the nutrients the child needs.

The results showed that most categories of family attachment were in the medium category, meaning that the family was not completely dependent or tied to other families. Children with nutritional problems can be seen in all categories of family attachment. Independent families in providing care to children including child feeding. According to Nurhayatia's (2020), kinship and social factors, cultural values and ways of life can increase the behavior of exclusive breastfeeding. The family has an important role in the care of children with nutritional problems. Families that have good family functions and have good emotional ties can support growth and development. Good family parenting is closely related to the nutritional status of children because parents will provide protection, education, and will care for their children with great affection. The family is the main supporting factor in feeding toddlers. Likewise, with the habits and patterns of feeding, in general, the mother follows the eating patterns and habits in the family.

\section{d. Cultural Values and Lifestyle}

One of the causes of nutritional problems is behavioral factors, which also have to do with habits and culture in childcare (Nurhayatia, 2020). Cultural habits affect the feeding patterns of children in terms of beliefs, values, and behaviors related to different foods. The results showed that the category of cultural values in caring for children was mostly in the moderate category. Cultural values and lifestyle still dominate in childcare. The family still refers to cultural values in providing care to children. Fulfillment of nutrition given by mothers to children often does not pay attention to children's nutritional adequacy. Mothers tend to provide adequate nutrition according to the child's wishes. The culture of feeding children before their time has become commonplace. Food consumption for toddlers is mostly not following the dietary rules for children according to age. If this situation continues, the toddler will be deficient in nutrients, so that it can inhibit the growth of the toddler. The dietary pattern of the community or group where the child is located will greatly affect the eating habits, appetite, and acceptance of the child for food. Families need eating habits for children that pay attention to health and nutrition. Parents should be able to instill a good, healthy, and regular lifestyle and diet in children so that children can grow and develop properly.

\section{e. Economic Status}

Socio-economic factors that affect nutritional status begin with the type of work that is influenced by the level of education so that low levels of education and unsuitable types of work will directly affect family income. The results showed that most families received good economic support. Families with good economic status tend to have children with good nutritional status. Children with families who have a high 
socioeconomic level, the need for nutritional substances will be fulfilled well compared to children who live with families with low socio-economic status.

Socio-economic status is a risk factor for malnutrition because the low socioeconomic status will have an impact on the purchasing power of food in the amount needed or can only meet basic needs in the form of carbohydrates, which is the main priority food. The low quality and quantity of food consumed is a direct cause of malnutrition in toddlers. Efforts to improve nutritional status include the presence of a nutritionally conscious family by utilizing the house yard planted with nutritious vegetables that can be consumed daily without having to spend money. Low family income can have a direct impact on the provision of food in the family, where the family will experience problems in the availability of food according to their needs so that it can impact and disrupt the nutritional status of children. The increase in income in the family means that it can also increase the opportunity to buy food or food of good quality and in an appropriate amount, on the other hand, a decreased or low income will also decrease the purchasing power of the family to fulfill quality foodstuffs in an appropriate amount which in turn can increase nutritional status as well as good nutritional intake (Sulistyoningsih, 2011).

\section{f. Parents Education}

A mother's education and knowledge can influence the proper feeding patterns of children. Maternal education and knowledge factors are important in choosing the type and amount of food and determining the child's feeding schedule so that the feeding pattern is appropriate and appropriate for children aged 1-3 years (Subarkah, et al., 2016).

According to Sholikah, et al. (2017) parents who have higher education will better understand food and choose good food for their children. Families with higher education are certainly easier than those with low educational backgrounds, especially those related to increasing child growth and development, use of health facilities, and so on.

Table 2. Components of the Sunrise Model on the nutritional status of toddlers

\begin{tabular}{lcr}
\hline $\begin{array}{l}\text { Sunrise Model Components } \\
\text { (Independent Factor) }\end{array}$ & Dependent Factors & p-Value \\
\hline Utilization of Health Technology & Toddler Nutritional Status & 0.025 \\
\hline Religion and Philosophy of Care & & 0.050 \\
\hline Family Attachments & & 0.007 \\
\hline Cultural values and lifestyle & & 0.006 \\
\hline Economic Status & & 0.017 \\
\hline Parents Education & & 0.001 \\
\hline
\end{tabular}

Table 2 shows that all variables have a significant relationship with the nutritional status of toddlers as indicated by $p=<0.05$. Toddlers are an age that is prone to changes in nutritional status because the growth process starting from the age of children under five greatly affects the quality of human growth in adolescence and even into adulthood. At this age, toddlers are also prone to nutrition and disease and are susceptible to changes in food consumption. Malnutrition and malnutrition are still a public health problem in Indonesia. A child often cannot fulfill good nutritional intake, for instance, due to family economic factors, education, and the number of families.

Hidayat \& Jahari's, (2013) stated that households that use health services have more children with good nutritional status and low morbidity, compared to those who do not 
Tat, F., Romana, A.B.Y.H., \& Shafie, Z. B. M. (2020). The Sunrise Model Approach to the Nutritional Status of Toddlers at the Kupang District Primary Health Care. JURNAL INFO KESEHATAN, 18(2),96-104.

utilize health services. It shows that the most dominant factor related to nutritional status is the type of work of the father and the type of work of the mother. Whereas, Purwaningrum \& Wardani's, (2012) shows that there is a relationship between food intake (energy and protein) with the nutritional status of children under five and there is a relationship between the status of Family Nutrition Awareness with the nutritional status of children under five. The various references above show that various factors can cause nutritional problems in toddlers, both direct causes, which are insufficient nutritional intake in toddlers, as well as indirect causes, that are influencing factors such as education level, socio-economy, culture, and beliefs.

\section{CONCLUSION}

There is a significant relationship between components in the sunrise model, which are the use of health technology, religious beliefs and family philosophy, family ties, cultural and lifestyle factors, family economic status, education of parents and nutritional status of children under five in Kupang Regency. It is suggested that the sunrise model approach can be used to fix nutritional problems in toddlers in Kupang Regency.

\section{REFERENCES}

Asemahagn, M. A. (2016). Determinants of Exclusive Breastfeeding Practices Among Mothers in Azezo District, Northwest Ethiopia. International Breastfeeding Journal, 11(1), 22. DOI:10.1186/s13006-016-0081-x

Azrimaidaliza, A., Annisa, A., Khairany, Y., Prativa, N., Adrianus, R., \& Salmah, M. P. (2019). A Optimalisasi Tumbuh Kembang Balita Melalui Promosi Gizi Seimbang Di Kecamatan Koto Tangah Padang. Logista-Jurnal Ilmiah Pengabdian kepada Masyarakat, 3(2), 17-26. DOI: 10.25077/logista.3.2(Jul-Des).17-26.2019

Fidiantoro, N., \& Setiadi, T. (2013). Model Penentuan Status Gizi Balita Di Puskesmas. Jurnal Sarjana Teknik Informatika, 1(1), 367-373.

Fitriyanti, F., \& Mulyati, T. (2012). Pengaruh Pemberian Makanan Tambahan Pemulihan (PMT-P) Terhadap Status Gizi Balita Gizi Buruk Di Dinas Kesehatan Kota Semarang Tahun 2012. Journal of Nutrition College, 1(1), 373-381. DOI: 10.14710/jnc.v1i1.436

Hidayat, T. S., \& Jahari, A. B. (2012). Perilaku Pemanfaatan Posyandu Hubungannya dengan Status Gizi dan Morbiditas Balita. Buletin Penelitian Kesehatan, 40(1), 110.

Henry, B.A., Nicolau, A.I., Américo, C.F., Ximenes, L.B., Bernheim, R.G. and Oriá, M.O. (2010). Socio-Cultural Factors Influencing Breastfeeding Practices among Low-Income Women in Fortaleza-Ceará-Brazil: a Leininger's Sunrise Model Perspective. Global Nursing. 9, 2 (1). DOI:10.6018/eglobal.9.2.106831.

Iskandar, I. (2017). Pengaruh Pemberian Makanan Tambahan Modifikasi Terhadap Status Gizi Balita. AcTion: Aceh Nutrition Journal, 2(2), 120-125. DOI: 10.30867/action.v2i2.65

Kemenkes, R. I. (2016). Profil Kesehatan Republik Indonesia. Jakarta: Kementerian Kesehatan Republik Indonesia.

Kupang City Health. (2016). Kupang City Health Profile 2016. Kupang: Kupang City Health. 
Meiranny, A. (2018). Pengetahuan Ibu tentang Kartu Menuju Sehat (KMS) Mempengaruhi Pertumbuhan Balita. Jurnal SMART Kebidanan, 4(2), 9-17. DOI: 10.34310/sjkb.v4i2.98

Nurhayatia, M. A., Armini, N. K. A., \& Kusumaningrum, T. (2020). Analysis of Breastfeeding Factors: The Sunrise Model Approach. Medico Legal Update, 20(1), 334-339. DOI: 10.37506/mlu.v20i1.380

Purwaningrum, S., \& Wardani, Y. (2013). Hubungan Antara Asupan Makanan dan Status Kesadaran Gizi Keluarga dengan Status Gizi Balita di Wilayah Kerja Puskesmas Sewon I, Bantul. Jurnal Kesehatan Masyarakat (Journal of Public Health), 6(3), 190-202. DOI:10.12928/kesmas.v6i3.1054

Poernomo, D. I. S. H., \& Anggraeni, S. (2011). Pengaruh Pemberian Makanan Tambahan Pemulihan (Pmt-P) Terhadap Pertumbuhan Balita Bawah Garis Merah (BGM) di Puskesmas Kota Wilayah Selatan Kediri. Jurnal Penelitian STIKES Kediri, 4(1), 17.

Rohmatun, K. I., \& Dewi, C. K. (2017). Pengaruh Pengetahuan Dan Religiusitas Terhadap Niat Beli Pada Kosmetik Halal Melalui Sikap. Jurnal Ecodemica, 1(1), 27-35.

Retnowati, D. H., Syamsianah, A., \& Handarsari, E. (2015). Pengaruh pemberian makanan tambahan pemulihan terhadap perubahan berat badan balita bawah garis merah kecacingan di wilayah Puskesmas Klambu Kabupaten Grobogan. Jurnal Gizi, 4(1), 30-36.

Sari, M. T., \& Prastianty, S. (2017). Sick Health Behaviors of the Jambi Malay Tribe Based on Transcultural Nursing Approach (Sunrise Model) at Muara Kumpeh Village Kumpeh Ulu District Muaro Jambi Regency. Jurnal Ilmiah Universitas Batanghari Jambi, 17(3), 216-226.

Sholikah, A. S., Rustiana, E. R., \& Yuniastuti, A. (2017). Faktor-faktor yang berhubungan dengan status gizi balita di pedesaan dan perkotaan. Public Health Perspective Journal, 2(1), 9-18.

Sudirman, S., \& Moonti, S. (2019). Hubungan Pengetahuan Dan Pengisian Kartu Menuju Sehat (KMS) Dengan Keaktifan Kader Posyandu Anak Balita Di Pustu Kalukubula Wilayah Kerja Puskesmas Biromaru Kabupaten Sigi. Jurnal Kolaboratif Sains, 1(1), 676-682.

Sukardin, Rahmani, Nurjanah, I., Endrawan, I. M.T. (2018). Hubungan Budaya Bali Dengan Status Gizi Balita Di Wilayah Kerja Puskesmas Tanjung Karang Kota Mataram. Prima: Jurnal Ilmiah Ilmu Kesehatan, 4(1), 103-110.

Sulistyoningsih, H. (2011). Gizi Untuk Kesehatan Ibu dan Anak. Yogyakarta: Graha Ilmu.

Subarkah, T., Nursalam, N., \& Rachmawati, P. D. (2017). Feeding Pattern Toward the Increasing of Nutritional Status in Children Aged 1-3 Years. Indonesian Nursing Journal of Education and Clinic (INJEC), 1(2), 146-154. DOI: 10.24990/injec.v1i2.120

Tristanti, I., \& Risnawati, I. (2017). Motivasi Kader Dan Kelengkapan Pengisian Kartu Menuju Sehat Balita Di Kabupaten Kudus. Indonesia Jurnal Kebidanan, 1(1), 111. DOI: $10.26751 /$ ijb.v1i1.221

Tulu, L. (2018). Gambaran Pengetahuan Ibu Balita Di Posyandu Tentang Kartu Menuju Sehat Balita Di Wilayah Kerja Puskesmas Plus Bara-Baraya Makassar Tahun 2018. Jurnal Farmasi Sandi Karsa, 4(7), 68-74. 